\title{
Spatial and temporal variation of natural toxicity in cnidarians, bryozoans and tunicates in Mediterranean caves*
}

\author{
RUTH MARTÍ ${ }^{1}$, MARIA-J. URIZ ${ }^{1}$ and XAVIER TURON ${ }^{2,+⿱ 亠 䒑}$ \\ ${ }^{1}$ Centre d'Estudis Avançats de Blanes - CSIC, Accés Cala Sant Francesc, 14, E-17300 Blanes, Girona, Spain. \\ ${ }^{2}$ Department of Animal Biology, Faculty of Biology, University of Barcelona, Diagonal Ave. 645, \\ E-08028 Barcelona, Spain. E-mail: xturon@ub.edu
}

\begin{abstract}
SUMMARY: The natural toxicity of cnidarians, bryozoans and tunicates in two caves was assessed using the Microtox ${ }^{\circledR}$ technique in spring and autumn. One cave was located in the Cabrera Archipelago (Balearic Islands) and the other in the Medes Islands (Catalan littoral). The organisms analysed were good representatives of the coverage of each Phylum in the communities; however, these Phyla are less abundant than sponges which are the dominant group in these caves. Seventy-one percent of the species of cnidarians and bryozoans analysed were toxic in one of the caves, communities or seasons, which indicates the relevance of bioactive species in these groups. The tunicate Lissoclinum perforatum was the most toxic species. Although all three Phyla had some highly toxic species, a common pattern that related the caves, communities and seasons was not found. Seasonal variation of toxicity in cnidarians and bryozoans was higher in the Cabrera than in the Medes cave. Moreover, variation in toxicity either between communities or between seasons was a common trait for most cnidarians and bryozoans, whereas tunicates remained toxic throughout communities and seasons.
\end{abstract}

Keywords: natural toxicity, cnidarians, bryozoans, tunicates, variation, Microtox ${ }^{\circledR}$ assay, caves.

RESUMEN: VARIACIÓN ESPACIAL Y TEMPORAL DE LA TOXICIDAD NATURAL EN CNIDARIOS, BRIOZOOS Y TUNICADOS DE CUEVAS MEDITERRÁNEAS. - Se analizó la toxicidad natural, mediante Microtox ${ }^{\circledR}$, de cnidarios, briozoos y tunicados de dos cuevas, en primavera y otoño. Una cueva estaba localizada en el Archipiélago de Cabrera (Islas Baleares) y la otra en las Islas Medas (Litoral Catalán). Los organismos analizados fueron una buena representación de los recubrimientos de cada Tipo en las comunidades de dichas cuevas, aunque eran menos abundantes que las esponjas, el grupo dominante. El setenta y uno por ciento de las especies analizadas de cnidarios y briozoos fueron tóxicas en alguna de las cuevas, comunidades o estaciones, indicando la relevancia de las especies bioactivas en estos grupos. El tunicado Lissoclinum perforatum fue la especie más tóxica. A pesar de que los tres Tipos presentaron algunas especies muy tóxicas, no se encontró un patrón común entre cuevas, comunidades o estaciones. La variación estacional de la toxicidad en cnidarios y briozoos fue mayor en la cueva de Cabrera que en la de las Islas Medes. Además, la variación de la toxicidad entre comunidades o entre estaciones fue habitual en cnidarios y briozoos, mientras que los tunicados tuvieron una toxicidad más bien constante entre comunidades y estaciones.

Palabras clave: toxicidad natural, cnidarios, briozoos, tunicados, variación, Microtox ${ }^{\circledR}$, cuevas.

\section{INTRODUCTION}

Corals and sponges are the most studied groups of benthic invertebrates in marine chemical ecology.

\footnotetext{
$\$$ Corresponding author
}

*Received November 2, 2004. Accepted March 1, 2005.
This is mainly because they are abundant in all seas (Jackson, 1977; Uriz et al., 1992). However, active secondary metabolites are also found in virtually all benthic invertebrates, including bryozoans (e.g. Walls et al., 1993; Shellenberger and Ross, 1998), tunicates (e.g. Costa et al., 1997; Vervoort et al., 1998; Koulman et al., 1999), echinoderms (e.g. 
Bandaranayake and des Rocher, 1999), and molluscs (e.g. Gavagnin et al., 2000).

Variation in secondary chemistry has been reported in seaweeds (e.g. Hay et al., 1988; Dworjanyn et al., 1999), sponges (e.g. Turon et al., 1996; Becerro et al., 1998; Schupp et al., 1999), and in several groups of cnidarians, including gorgonians (Harvell et al., 1993), soft corals (Maida et al., 1993; Kelman et al., 2000), and octocorals (Harvell and Fenical, 1989; Van Alstyne and Paul, 1992).

A number of ecological functions of toxicity have been postulated, such as antipredatory (e.g. cnidarians: Van Alstyne et al., 1992. Tunicates: Vervoort et al., 1998;), antifouling (e.g. cnidarians: Jensen et al., 1996. Bryozoans: Walls et al., 1993; Shellenberger and Ross, 1998), and spatial competition (e.g. cnidarians: Koh and Sweatman, 2000). Soft corals have been reported to release secondary metabolites into the environment (Coll et al., 1982). Secondary metabolites may be crucial in mediating competitive interactions between encrusting organisms in space-limited communities (Jackson and Buss, 1975).

In this paper we studied the patterns of spatial and temporal variation of natural toxicity in benthic invertebrates of several Phyla. We analysed the natural toxicity of the most abundant species of cnidarians, bryozoans and tunicates in distinct communities of two Mediterranean caves. Moreover, to assess seasonal variation of natural toxicity, analyses were done in June (spring) and November (autumn).

\section{MATERIAL AND METHODS}

\section{Study site}

Sampling was performed by SCUBA diving along a horizontal transect in two Mediterranean caves in June and November 1996 and 1997. These caves are located in the Cabrera (Balearic Islands) and the Medes (Catalan littoral) Archipelagos respectively. In the Cabrera cave, three communities were sampled from the entrance to the inner part: a sciaphilic seaweed community (SSC) at the entrance, an external semi-dark cave community (ESC), and an internal semi-dark community (ISC). In the Medes cave, four communities were sampled: a hemisciaphilic seaweed community (HSM) located outside the cave, an external semi-dark cave community (ESM) at the entrance, a more internal semi-dark community (ISC), and a dark cave community (DCM) in the innermost part. The communities studied corresponded to zones 2, 3 and 4 in the Cabrera cave and zones 1, 2, 3 and 4 in the Medes cave; these zones have been described previously in (Martí et al., 2004a).

Whenever available biomass allowed, we collected replicates for each species. For small cnidarians, such as Polycyathus muellerae (Abel, 1959), Leptopsammia pruvoti (Lacaze-Duthiers, 1897), and Parazoanthus axinellae (Schmidt, 1862), replicates consisted of groups of adjacent polyps taken from different patches at least $1 \mathrm{~m}$ apart. For bryozoans and colonial tunicates, as each colony was clearly delimited, replicates were distinct individuals or colonies of the same species located at least $1 \mathrm{~m}$ apart. Lissoclinum perforatum (Giard, 1871), was the exception because of the small size of the colonies, so that the replicates consisted of 13 spatially close colonies that were then pooled.

\section{Chemical extraction}

In the laboratory the samples were cleaned of epibionts and separated from the substratum and any foreign material. They were then frozen, lyophilised and stored for posterior chemical extraction. A known weight of each lyophilised sample was extracted three successive times in $10 \mathrm{ml}$ of methanol for 5, 10 and 15 minutes respectively, using an ultrasonic bath. The solvent from these extractions was filtered, pooled and evaporated under reduced pressure and nitrogen stream. The dry crude extracts were then weighed and kept at $-20 \mathrm{C}^{\mathrm{o}}$ until dilution in artificial seawater for the Microtox ${ }^{\circledR}$ assay.

\section{Toxicity analyses}

Just before performing Microtox ${ }^{\circledR}$ analyses (Becerro et al., 1995, Martí et al., 2003), which analyse toxicity against a marine photobacterium, dried crude extracts were dissolved in artificial sea water to obtain a final concentration of $1000 \mu \mathrm{g}$ crude extract $\mathrm{ml}^{-1}$. Since the dilution factor was 2 , the concentrations tested were $500 \mu \mathrm{g} \mathrm{ml}^{-1}, 250 \mu \mathrm{g}$ $\mathrm{ml}^{-1}, 125 \mu \mathrm{g} \mathrm{ml}^{-1}$ and $62.5 \mu \mathrm{g} \mathrm{ml}^{-1}$ (50\%, 25\%, $12.5 \%$ and $6.25 \%$ of the initial concentration of $\left.1000 \mu \mathrm{g} \mathrm{ml}^{-1}\right)$.

To compare the results of the different samples, we used the gamma value (toxicity) of the 
concentration corresponding to a $1 \mathrm{mg}$ sample DW $\mathrm{ml}^{-1}$. The toxicity of this concentration was obtained by using the resulting regression equation of the Microtox ${ }^{\circledR}$ assay (see Martí et al., 2003). By referring the results to the same concentration relative to sample DW, we could compare all the samples even when their DWs differed and the proportions of crude extract $\mathrm{DW}^{-1}$ varied in the different species.

We selected a threshold to discern between toxic and non-toxic species by comparing two distinct toxicity analyses: the Microtox ${ }^{\circledR}$ and sea-urchin test. All species assayed from different Phyla showed activity against sea-urchin embryos at 0.5 gamma units of Microtox ${ }^{\circledR}$ assay, therefore we selected this value as our threshold (see Martí et al., 2004b, for a more detailed explanation).

\section{Statistical analyses}

Seasonal changes in toxicity were statistically analysed for each species. We performed t-tests to find differences between seasons for the species present in only one community. Species in more than one community in a single cave were analysed by two-way ANOVA with season and community as the factors. Unless otherwise stated, Tukey post-hoc tests were used for a posteriori comparisons. In all cases, when data did not meet the assumptions of normality (KolmogorovSmirnov test) and homoscedasticity (Bartlett test), rank transformation was carried out and parametric analyses were performed on ranked data (Conover and Iman, 1981; Potvin and Roff, 1993). All the analyses were done with the Systat v 5.0 and Statistica v 4.0 packages.

\section{RESULTS}

\section{Cnidarians}

\section{The Cabrera cave}

We analysed 4 cnidarian species from SSC, which accounted for $83 \%$ and $86 \%$ of the cnidarian coverage in June and November respectively; 4 species from ESC, which accounted for $100 \%$ of coverage in the two seasons; and 4 species from ISC, which represented $83 \%$ and $99 \%$ of coverage in June and November respectively (Table 1).

Specimens of Clavularia crassa (MilneEdwards, 1848), and Eudendrium sp. were only analysed in November. Both species were toxic (Table 2). Madracis pharensis (Heller, 1868), was never toxic. The behaviour of $P$. muellerae differed in each community and season: its toxicity increased from June to November in SSC, decreased during the same period in ESC and it was not toxic in ISC.

For species with replicate samples, $L$. pruvoti was only toxic in ISC, where it showed decreased toxicity from June to November (Fig. 1). The results from the ANOVA showed that community and season had significant effects on toxicity (Table 2). Post-hoc analysis for differences among communities indicated that SSC and ESC were similar ( $p>$ $0.05)$, but they differed from ISC, which was more toxic ( $p<0.05$ and $\mathrm{p}<0.005$ respectively). The season was also significant $(\mathrm{p}<0.05)$ : toxicity was higher in June than in November in all communities.

P. axinellae was the most toxic cnidarian (Fig. 1). This species was significantly more toxic in ISC than in ESC (Table 2). It is interesting to note that the standard error of the mean toxicity for all the cnidarians

TABLE 1. - Toxicity (gamma units) of cnidarians from the Cabrera and Medes caves in both seasons. SSC, ESC and ISC = sciaphilic seaweed community and external and internal semi-dark cave communities in the Cabrera cave respectively. ESM, ISM and DCM = external and internal semi-dark cave communities and dark cave community in the Medes cave respectively.

\begin{tabular}{|c|c|c|c|c|c|c|}
\hline \multirow[t]{2}{*}{ Species and authorities } & \multicolumn{2}{|c|}{ SSC } & \multicolumn{2}{|c|}{ ESC } & \multicolumn{2}{|c|}{ ISC } \\
\hline & June & Nov. & June & Nov. & June & Nov. \\
\hline Clavularia crassa (Milne-Edwards, 1848) & & 1.31 & & & & \\
\hline Eudendrium sp. & & 1.22 & & & & \\
\hline »Leptopsammia pruvoti Lacaze-Duthiers, 1897 & 0.35 & 0.32 & 0.40 & 0.39 & 0.80 & 0.51 \\
\hline Madracis pharensis (Heller, 1868) & & & 0.35 & 0.32 & 0.32 & 0.44 \\
\hline »Parazoanthus axinellae (Schmidt, 1862) & & & 2.04 & 1.63 & 3.69 & 2.59 \\
\hline \multirow[t]{2}{*}{ Polycyathus muellerae (Abel, 1959) } & 0.44 & 1.28 & 0.78 & 0.46 & 0.28 & 0.44 \\
\hline & \multicolumn{2}{|c|}{ ESM } & \multicolumn{2}{|c|}{ ISM } & \multicolumn{2}{|c|}{ DCM } \\
\hline & June & Nov. & June & Nov. & June & Nov. \\
\hline Corallium rubrum (Linnaeus, 1758) & 0.02 & 0.01 & 0.01 & 0.08 & & \\
\hline »Leptopsammia pruvoti Lacaze-Duthiers, 1897 & 0.35 & 0.36 & 0.65 & 0.46 & 0.55 & 0.47 \\
\hline
\end{tabular}

» indicates species for which replicates were obtained and thus toxicity values are means 

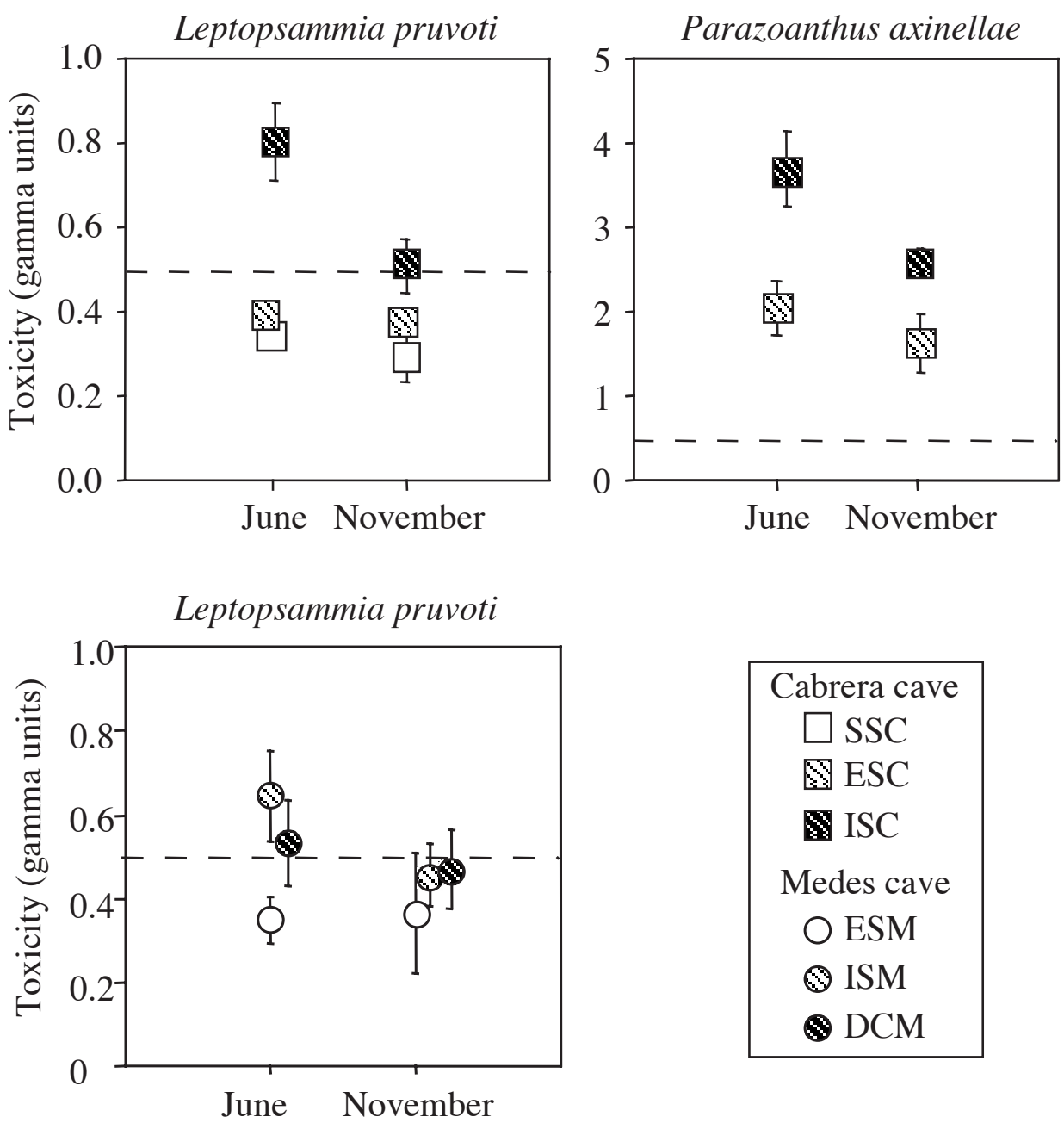

FIG. 1. - Mean toxicity and standard error of cnidarians in the Cabrera and Medes caves. The dashed line indicates the 0.5 gamma threshold between toxic and non-toxic species. The abbreviations of communities are SSC, ESC and ISC: sciaphilic seaweed community and external and internal semi-dark cave communities in the Cabrera cave respectively. ESM, ISM and DCM: external and internal semi-dark cave communities and dark cave community in the Medes cave respectively.

analysed was notably smaller than that observed for algae (Martí et al., 2004b), and sponges (Martí, 2002), under the same environmental conditions, which indicates a lower genotypic variability.

\section{The Medes cave}

We analysed Corallium rubrum (Linnaeus, 1758), and L. pruvoti in the Medes cave (Table 1). In ESM, these two species accounted for $94 \%$ of the total cnidarian coverage in June and $96 \%$ in November. For ISM, the percentages were also high: $80 \%$ in June and $93 \%$ in November. Only L. pruvoti was analysed in DCM (where it had low coverage). $C$. rubrum was never toxic. L. pruvoti was toxic only in June in ISM and DCM. Differences among communities and between seasons (Fig. 1) were lower than those detected in the Cabrera cave. Although species tended to show higher toxicity in
June, statistical differences were not detected between seasons (Table 2).

\section{Bryozoans}

\section{The Cabrera cave}

In SSC, two species accounted for $69 \%$ and $62 \%$ of the bryozoan coverage in June and November respectively. Five species from ESC, which accounted for $61 \%$ of coverage in June and $64 \%$ in November, were also analysed. Only Frondipora verrucosa (Lamouroux, 1821), was analysed from ISC, and it accounted for $12 \%$ and $15 \%$ of coverage. Most species experienced high seasonal changes in coverage (Martí et al., 2004a) and were detected only in one season (Table 3).

Schizomavella sp. and Smittina cervicornis (Pallas, 1766) were never toxic. Sertella sp. and 
TABLE 2. - Two-way ANOVA results on toxicity of cnidarians from the Cabrera and Medes caves.

\begin{tabular}{|c|c|c|c|c|c|}
\hline \multicolumn{6}{|c|}{$\begin{array}{l}\text { Leptopsammia pruvoti } \\
\text { from SSC, ESC and ISC of the Cabrera cave. }\end{array}$} \\
\hline Community & 0.343 & 2 & 0.172 & 15.991 & 0.004 \\
\hline Season & 0.058 & 1 & 0.058 & 5.421 & 0.038 \\
\hline$C * S$ & 0.073 & 2 & 0.036 & 3.383 & 0.068 \\
\hline Error & 0.129 & 12 & 0.011 & & \\
\hline
\end{tabular}

Parazoanthus axinellae from ESC and ISC in the Cabrera cave.

\begin{tabular}{lcccrl} 
Source & SS & DF & MS & \multicolumn{1}{c}{ F } & P \\
\hline Community & 5.116 & 1 & 5.116 & 15.324 & 0.004 \\
Season & 1.706 & 1 & 1.706 & 5.111 & 0.054 \\
C*S & 0.356 & 1 & 0.356 & 1.067 & 0.334 \\
Error & 2.671 & 8 & 0.334 & & \\
\hline
\end{tabular}

Leptopsammia pruvoti

from ESM, ISM and DCM in the Medes cave.

\begin{tabular}{lcrlll} 
Source & SS & DF & MS & F & P \\
\hline Community & 0.064 & 1 & 0.064 & 2.143 & 0.160 \\
Season & 0.032 & 1 & 0.032 & 1.058 & 0.324 \\
C*S & 0.016 & 2 & 0.016 & 0.532 & 0.601 \\
Error & 0.360 & 12 & 0.030 & &
\end{tabular}

Myriapora truncata (Pallas, 1766) were more toxic in November than in June. For the species for which we had replicates (Fig. 2), Scrupocellaria sp. did not show significant differences in toxicity between communities ( $p>0.05)$, but this species was clearly toxic in June, and its toxicity was close to 0.5 gamma in November. F. verrucosa was always toxic but high variability prevented significant differences being detected either between communities or between seasons (Fig. 2 and Table 4).

\section{The Medes cave}

As most bryozoans were extraordinarily small encrusting or branching forms, it was difficult to obtain enough material for the toxicity analysis. Only 3 species were analysed in the two seasons (Table 3).

The species from ESM accounted for a low percentage of total bryozoans present in the communi-

TABLE 3. - Toxicity (gamma units) of bryozoans from the Cabrera and Medes caves in both seasons. SSC, ESC and ISC $=$ sciaphilic seaweed community and external and internal semi-dark cave communities in the Cabrera cave respectively. ESM and DCM = external semi-dark cave community and dark cave community in the Medes cave respectively.

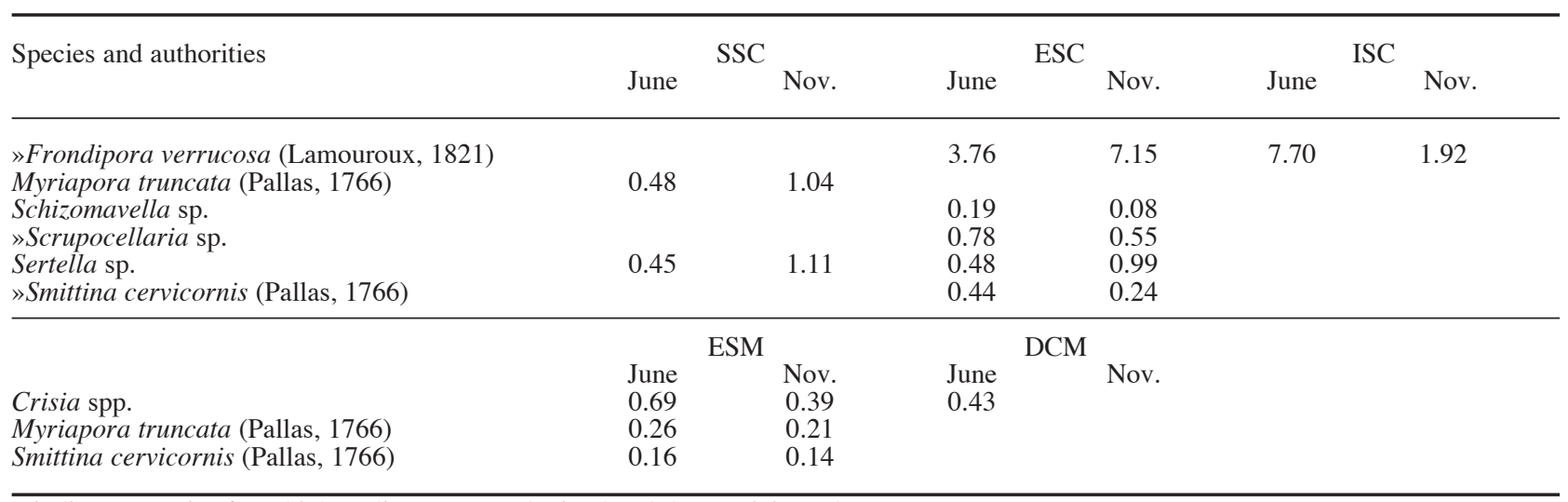

» indicates species for which replicates were obtained and thus toxicity values are means
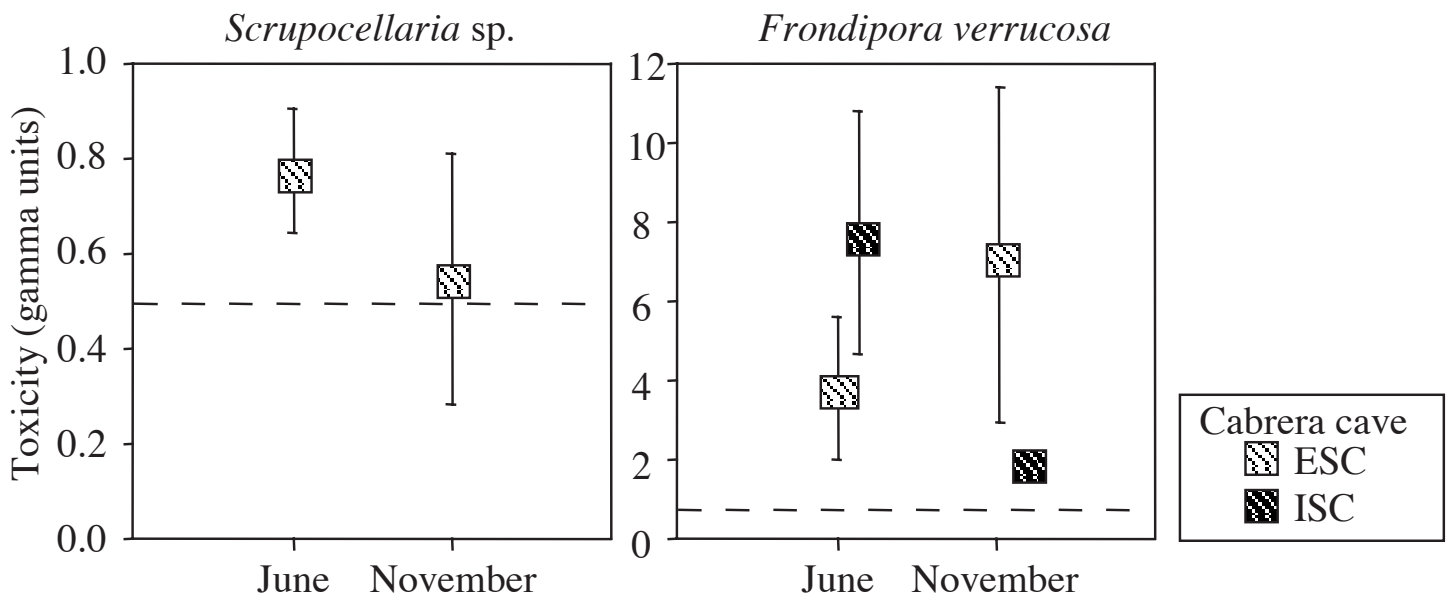

FIG. 2. - Mean toxicity and standard error of bryozoans in the Cabrera cave. The dashed line indicates the 0.5 gamma value threshold between toxic and non-toxic species. The abbreviations of communities are ESC and ISC: external and internal semi-dark cave communities respectively. 
TABLE 4. - Two-way ANOVA results on toxicity of Frondipora verrucosa from the ESC and ISC in the Cabrera cave.

\begin{tabular}{lrrrrl}
\hline Source & \multicolumn{1}{l}{ SS } & DF & MS & F & P \\
\hline Community & 1.244 & 1 & 1.244 & 0.054 & 0.822 \\
Season & 4.308 & 1 & 4.308 & 0.188 & 0.676 \\
C*S & 62.993 & 1 & 62.993 & 2.751 & 0.136 \\
Error & 183.158 & 8 & 22.895 & & \\
\hline
\end{tabular}

ty (6.7\%). Only the small species Crisia spp. was toxic in ESM in June.

\section{Tunicates}

\section{The Cabrera cave}

Tunicates were scarce and very small in this cave. We only studied $L$. perforatum from ISC and found it to be extraordinarily toxic, with a mean toxicity of 212.2 gamma units in June, and in November all the test bacteria were killed at the concentrations tested. The toxicity of this species was one of the highest detected in this study, and is comparable to that of the highly toxic sponge Crambe crambe (Schmidt, 1862) (Becerro et al., 1997; Martí, 2002).

\section{The Medes cave}

There were sufficient quantities of two species to perform toxicity analyses in the Medes cave in both seasons (Table 5). Didemnum sp. was not toxic in any season. Toxicity of Cystodytes dellechiajei (Della Valle, 1877), did not vary significantly (Table 6) between communities and seasons (Fig. 3).

\section{DISCUSSION}

Most of the cnidarians analysed $(71 \%)$ in this study were toxic in at least one cave, community or season. None of the species had epibionts (Uriz et $a l ., 1991$ and personal observation), therefore toxic-
TABle 6. - Two-way ANOVA results on toxicity of Cystodytes dellechiajei from HSM and ESM in the Medes cave.

\begin{tabular}{llllll}
\hline Source & SS & DF & MS & F & P \\
\hline Community & 0.0004 & 1 & 0.0004 & 0.163 & 0.902 \\
Season & 0.004 & 1 & 0.004 & 0.157 & 0.702 \\
C $*$ S & 0.024 & 1 & 0.024 & 0.985 & 0.351 \\
Error & 0.195 & 8 & 0.024 & & \\
\hline
\end{tabular}
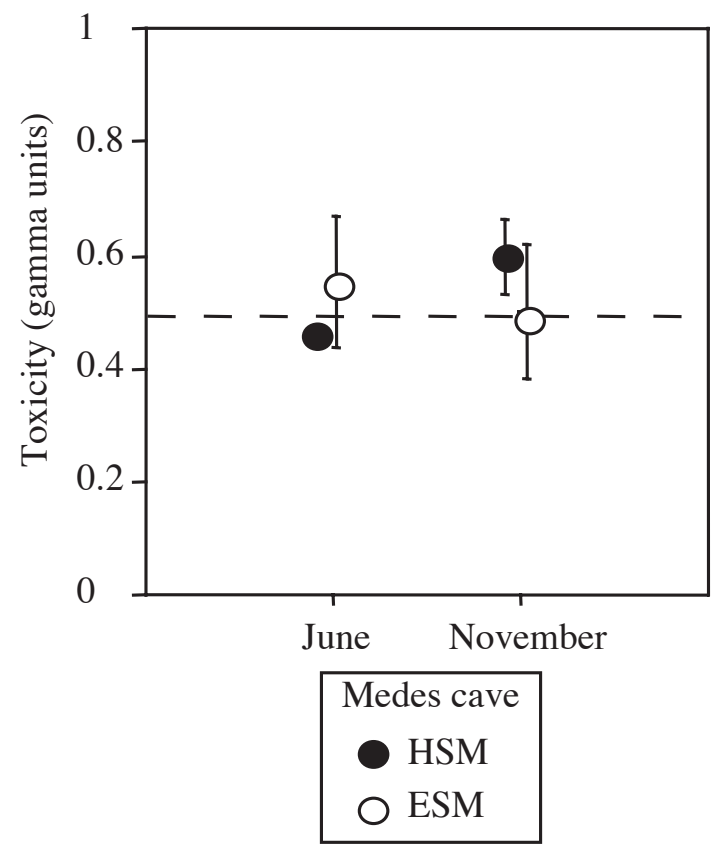

FIG. 3. - Mean toxicity and standard error of Cystodytes dellechia$j e i$ in the Medes cave. The dashed line indicates the 0.5 gamma threshold between toxic and non-toxic species. The abbreviations of communities are HSM: hemisciaphilic seaweed community and ESM: external semi-dark cave community.

ity may be an antifouling strategy, although further experimental evidence is required. Previous studies have addressed toxicity variations in cnidarians. The secondary metabolites of some species can vary quantitatively and qualitatively, depending on the biogeographic zone (Harvell et al., 1993), while other species have similar compositions of these metabolites in different habitats (Puglisi et al., 2000). The toxic behaviour of some cnidarians in this study is comparable to that of other cnidarian

TABLE 5. - Toxicity (gamma units) of the tunicates analysed from the Medes cave in both seasons. HSM = hemisciaphilic seaweed community, ESM = external semi-dark cave community, DCM = dark cave community.

\begin{tabular}{|c|c|c|c|c|c|c|c|c|}
\hline Species and authorities & HSM & ESM & $\underset{\text { June }}{\text { DCM }}$ & Nov. & June & Nov. & June & Nov. \\
\hline \multicolumn{3}{|c|}{$\begin{array}{l}\text { »ystodytes dellechiajei (Della Valle, 1877) } \\
\text { Didemnum sp. } 1\end{array}$} & 0.55 & 0.50 & 0.47 & 0.60 & 0.08 & 0.01 \\
\hline
\end{tabular}

» indicates species for which replicates were obtained and thus toxicity values are means 
species. For instance, the toxicity of $P$. axinellae in the Cabrera cave varied significantly in the different communities: it was more toxic in ISC than in ESC. If we consider that the innermost zones of caves are comparable to deep habitats (Vacelet et al., 1993), this toxicity pattern is in accordance with that of a gorgonian species (Harvell et al., 1993). This study reported a significantly higher concentration of secondary metabolites in gorgonian specimens transplanted to deep habitats than in those that remained in the shallow habitats.

A total of $71 \%$ of the bryozoans were toxic in one of the communities, caves or seasons. There are few studies on the bioactivity of bryozoans (Martín and Uriz, 1993; Walls et al., 1991, 1993; Shellenberger and Ross, 1998). In the Mediterranean Sea, bryozoans are one of the most active taxa along with sponges and tunicates (Uriz et al., 1991). Martín and Uriz (1993), found strong biocide and anti-settlement activities in the extracts of Myriopora truncata and Sertella beaniana, while anti-mitotic or cytotoxic activities were moderate. F. verrucosa showed high intra-specimen variation in toxicity, with some highly active specimens compared to other bryozoans and most species of the other Phyla.

The bryozoans analysed here were usually quite free of epibionts and the antifouling role is the most commonly reported function for chemical defence in this group. Walls et al. (1993), and Shellenberger and Ross (1998), reported a negative correlation between the presence of secondary metabolites, the antibacterial activity of the extracts and a reduction of fouling, which might indicate an antifouling function for secondary metabolites. These authors also hypothesised that secondary metabolites in bryozoans contribute to inhibiting surface microbial films, which in turn influences the type of organisms that settle on them. The antifouling function of secondary metabolites in bryozoans is also reported in other studies (Walls et al., 1991). There is only one analysis of the variation of natural compound production in bryozoans. The secondary metabolites called bryostatins, which strongly inhibit human cancer, are synthesized only by some populations of Bugula neritina (Linnaeus, 1758) (Pettit, 1991). We also detected seasonal and spatial variation in toxicity in some bryozoans.

Antitumour, antileukemic, cytotoxic, antiviral and immunosuppressive molecules have been isolated from tunicates (Costa et al., 1997; Koulman et al., 1999). Tunicates are one of the Phyla with a higher percentage of toxic species in the Mediterra- nean (Uriz et al., 1991). We detected a large interspecies variation in toxicity in the three species analysed: one was highly toxic (i.e. L. perforatum), another mildly toxic (i.e. C. dellechiajei) and a third was not toxic (i.e. Didemnum sp.). L. perforatum was the most active organism in this study.

We conclude that all the Phyla considered have some toxic representatives but that species toxicity does not show a common pattern between caves, communities and seasons. Toxicity varied with season and/or community in most cnidarians and bryozoans, whereas the tunicates remained toxic throughout the communities and seasons.

\section{ACKNOWLEDGEMENTS}

This research was funded by projects REN20012312 and CTM2004-05265 of the Spanish Government and by the Interreg IIIA-1-72-E project of the European Union. R.M was supported by a postgraduate fellowship from the Catalan Government and a post-doctoral fellowship from the Spanish Government. We acknowledge the logistic support and permits for diving and collecting granted by the Cabrera National Park (Balearic Islands). We particularly thank E. Ballesteros for help with the sampling. We also thank E. Cebrian, N. Sant and M. Ballesteros for their help with the sampling and G. Agell, M. Bardají and N. Llambí for assistance in the laboratory.

\section{REFERENCES}

Bandaranayake, W.M. and A. des Rocher. - 1999. Role of secondary metabolites and pigments in the epidermal tissue, ripe ovaries, viscera, gut contents and diet of the sea cucumber Holothuria atra. Mar. Biol., 133(1): 163-169.

Becerro, M.A., M.J. Uriz, and X. Turon. - 1995. Measuring toxicity in marine environment: critical appraisal of three commonly used methods. Experientia, 51: 414-418.

Becerro, M.A., M.J. Uriz. and X. Turon. - 1997. Chemically-mediated interactions in benthic organisms: the chemical ecology of Crambe crambe (Porifera, Poesilosclerida). Hydrobiologia, 356: 77-89.

Becerro, M.A, J.V. Paul, and J. Starmer. - 1998. Intracolonial variation in chemical defenses of the sponge Cacospongia sp. and its consequences on generalist fish predators and the specialist nudibranch predator Glossodoris pallida. Mar. Ecol. Prog. Ser., 168: 187-196.

Coll, J.C., B.F. Bowden, D.M. Tapiolas and W.C. Dunlap. - 1982. In situ isolation of allelochemicals released from soft corals (Coelenterata: Octocorallia): A totally submersible sampling apparatus. J. Exp. Mar. Biol. Ecol., 60: 293-299.

Conover, W.O. and R.L. Iman. - 1981. Rank transformation as a bridge between parametric and nonparametric statistics. Am. Stat., 35: 124.

Costa, L.V., J.C. Freitas, M.A.A. Sanchez, R.G.S. Berlinck, R.M. Rocha and S.A. Rodrigues. - 1997. Cytotoxic activity in extracts of tunicates from Brazilian coast. J. Venom. Anim. Toxins., 3(1): 194. 
Dworjanyn, S.A., R. de Nys and P.D. Steinberg. - 1999. Localisation and surface quantification of secondary metabolites in the red alga Delisea Pulchra. Mar. Biol., 133: 727-736.

Gavagnin, M., E. Mollo, D. Montanaro, J. Ortea and G. Cimino. 2000. Chemical studies of Caribbean sacoglossans: dietary relationships with green algae and ecological implications. $J$. Chem. Ecol., 26(7): 1563-1578.

Harvell, C.D. and W. Fenical - 1989. Chemical and structural defenses of Caribbean gorgonians (Pseudopterogorgia spp.): intracolony localization of defense. Limnol. Oceanogr., 34: 382-389.

Harvell, C.D., W. Fenical, V. Roussi, J.L. Ruesink, C.C. Griggs and C.H. Greene. - 1993. Local and geographic variation in the defensive chemistry of a West Indian gorgonian coral (Briareum asbestinum). Mar. Ecol. Prog. Ser., 93: 165-173.

Hay, M.E., P.E. Renaud and W. Fenical. - 1988. Large mobile versus small sedentary herbivores and their resistance to seaweed chemical defenses. Ecology, 75: 246-252.

Jackson, J.B.C., and L.W. Buss. - 1975. Allelopathy and spatial competition among coral reef invertebrates. Proc. Nat. Acad. Sci. USA., 72: 5160-5163.

Jackson, J.B.C. - 1977. Competition on marine hard substrata: the adaptive significance of solitary and colonial strategies. Am. Nat., 3: 743-767.

Jensen, P.R., C.D. Harvell, K. Wirtz and W. Fenical. - 1996. Antimicrobial activity of extracts of Caribbean gorgonian corals. Mar. Biol., 125(2): 411-419.

Kelman, D., Y. Benayahu and Y. Kashman. - 2000. Variation in secondary metabolite concentrations in yellow and grey morphs of the Red Sea soft coral Parerythropodium fulvum fulvum: possible ecological implications. J. Chem. Ecol., 26(5): 1123-1134.

Koh, E.G.L. and H. Sweatman. - 2000. Chemical warfare among scleractinians: bioactive natural products from Tubastraea faulkneri Wells kill larvae of potential competitors. J. Exp. Mar. Biol. Ecol., 251: 141-160.

Koulman, A., L.M.C. Pruijn, T.S.A. Sandstra, H.J. Woerdenbag, and N. Prass - 1999. The pharmaceutical exploration of cold water ascidians from the Netherlands: a possible source of new cytotoxic natural products. J. Biotechnol., 70(1-3): 85-88.

Maida, M. Carroll, A. R. and J.C: Coll - 1993. Variability of terpene content in the soft coral Inularia flexibilis (Coelenterata: Octocorallia), and its ecological implications. J. Chem. Ecol., 19(10): 2285-2296.

Martí, R. - 2002. Spatial and temporal variation of the natural toxicity in benthic communities of Mediterranean caves. PhD. Thesis (University of Barcelona).

Martí, R., A. Fontana, M.J. Uriz and G. Cimino. - 2003. Quantitative assessment of natural toxicity in sponges: toxicity bioassay versus compound quantification. J. Chem. Ecol., 29(6): 1307-1318.

Martí, R., M.J. Uriz, E. Ballesteros, and X. Turon. - 2004a. Benthic assemblages along two Mediterranean caves: differences in species diversity and coverage as a function of abiotic parameters and geographic distance. J. Mar. Biol. Ass. U. K., 84: 557-572.
Martí, R., M.J. Uriz and X. Turon. - 2004b. Seasonal and spatial variation of species toxicity in Mediterranean seaweed communities: correlation to biotic and abiotic factors. Mar. Ecol. Prog. Ser., 282: 73-85.

Martín, D. and M.J. Uriz. - 1993. Chemical bioactivity of Mediterranean benthic organisms against embryos and larvae of marine invertebrates. J. Exp. Mar. Biol. Ecol., 173: 11-27.

Pettit, G.R. - 1991. The bryostatins. Prog. Chem. Org. Nat. Prod., 57: 153-195

Potvin, C. and D.A: Roff. - 1993. Distribution-Free and robust statistical methods: viable alternatives to parametric statistics? Ecology, 74(6): 1617-1628.

Puglisi, M.P., V.J. Paul and M. Slattery. - 2000. Biogeographic comparisons of chemical and structural defenses of the Pacific gorgonians Annella mollis and A. reticulata. Mar. Ecol. Prog. Ser., 207: 263-272.

Schupp, P., C. Eder, V.J. Paul and P. Proksch. - 1999. Distribution of secondary metabolites in the sponge Oceanapia sp. and its ecological implications. Mar. Biol., 135: 573-580.

Shellenberger, J.S. and J.R.P. Ross. - 1998. Antibacterial activity of two species of bryozoans from northern Puget Sound. Northwest Sci., 72(1): 23-33.

Turon, X., M.A. Becerro and M.J. Uriz. - 1996. Seasonal patterns of toxicity in benthic invertebrates: the encrusting sponge Crambe crambe (Poecilosclerida). Oikos, 75: 33-40.

Uriz, M.J., D. Martín, X. Turon, E. Ballesteros, R. Hughes and C. Acebal. - 1991. An approach to the ecological significance of chemically mediated bioactivity in Mediterranean benthic communities. Mar. Ecol. Prog. Ser., 70: 175-188.

Uriz, M.J., D. Rosell and D. Martín. - 1992. The sponge population of the Cabrera archipelago (Balearic Islands): characteristics, distribution, and abundance of the most representative species. Mar. Ecol., 13: 101-107

Vacelet, J., N. Boury-Esnault and J.G. Harmelin. - 1993 Hexactinellid Cave, a unique deep-sea habitat in the scuba zone. Deep Sea Res., 41(7): 965-973.

Van Alstyne, K.L. and V.J. Paul. - 1992. Chemical and structural defenses in the sea fan Gorgonia ventalina: effects against generalist and specialist predators. Coral reefs, 11: 155-159.

Van Alstyne, K.L., C.R. Wylie, V.J. Paul and K. Meyer. - 1992. Antipredator defenses in tropical Pacific soft corals (Coelenterata: Alycyonacea). I. Sclerites as defenses against generalist carnivorous fishes. Biol. Bull., 182: 231-240.

Vervoort, H.C., J.R. Pawlikand and W. Fenical. - 1998. Chemical defenses of the Caribbean ascidian Didemnum conchyliatum. Mar. Ecol. Prog. Ser., 164: 221-228.

Walls, J.T., A.J. Blackmans and D.A. Ritz. - 1991. Distribution of amathamide alkaloids within single colonies of the bryozoan Amathia wilsoni. J. Chem. Ecol., 17: 1871-1881.

Walls, J.T., D.A. Ritz, and A.J. Blackman. - 1993. Fouling, surface bacteria and antibacterial agents of four bryozoan species found in Tasmania, Australia. J. Exp. Mar. Biol. Ecol., 169(1): 1-13.

Scient. ed.: P. Abelló 